\title{
Mesozoic geology and palaeogeography of Hochstetter Forland, East Greenland
}

\author{
FINN SURLYK
}

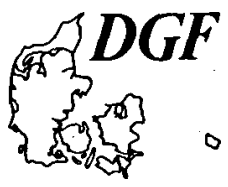

Surlyk, F.: Mesozoic geology and palaeogeography of Hochstetter Forland, East Greenland. Bull. geol. Soc. Denmark, vol. 27, pp. 73-87. Copenhagen, Öctober 1 st 1978.

https://doi.org/10.37570/bgsd-1978-27-07

Recent field work in the flat, low-lying Hochstetter Forland has resulted in a revision of earlier ideas about the stratigraphy and structure of the area. Structurally the area is composed of several southwestward and westward dipping fault-blocks limited by a main roughly N-S trending fault-system and by a system of NW-SE trending cross-faults. The lithostratigraphic scheme currently in use for other Mesozoic areas of East Greenland can be extended to Hochstetter Forland and only one member has been created especially for rocks on this peninsula. All units are coarser grained, markedly thinner and somewhat younger than those immediately to the south on Kuhn $\emptyset$.

The ?Middle - Upper Jurassic sandy shallow marine Pelion Member of the Vardekløft Formation (Jameson Land Group) rests directly on the peneplaned and tilted Caledonian basement with a basal conglomerate and interfingers with the coal-bearing lagoonal/shallow marine sandy Muslingebjerg Mem-ber. It is followed by Lower Kimmeridgian dark sandy offshore mudstones of the Bernbjerg Formation. The overlying syntectonic Wollaston Forland Group is represented by condensed grey and red mudstones of the Valanginian Albrechts Bugt and Rødryggen Members respectively. This is the first documentation of Valanginian rocks on Hochstetter Forland.

A sequence of fine-frained sandstone and intraformational conglomerates in a new locality on the extreme north-eastem coast is with hesitation correlated with the coarser grained parts of the Albrechts Bugt Member at Niesen, northern Wollaston Forland. The presence of Aptian sediments has been proved for the first time. They occur on the east coast, north of Kap Oswald Heer. Finally a geological sketch map of the area is presented and the Hochstetter Forland block is interpreted as occupying a proximal position in a Jurassic 'failed arm'.

Finn Surlyk, Geologisk Museum, Øster Voldgade 5-7, DK-1350 Copenhagen K., Denmark, September 8th, 1977.

Hochstetter Forland $\left(75^{\circ} 10^{\prime}-75^{\circ} 57^{\prime} \mathrm{N}\right)$ forms a low-lying flat area $90 \mathrm{~km}$ long and $30 \mathrm{~km}$ wide (fig. 1). It is mainly covered with bogs, heath and numerous small lakes, and exposures of prePleistocene rocks are poor and widely scattered. Consequently the area has been very unattractive to geologists working in the Mesozoic strata. The Second German North Polar Expedition collected the first geological information and brought back small fossil collections mainly from the south-west and east coast of Hochstetter Forland (Toula 1874). The 'Danmark Ekspedition' (1906-1908) also visited the coal-bearing sandstones at the southwest coast and the collected faunas were described by Ravn (1911), who demonstrated the presence of Upper Oxfordian and Kimmeridgian. Structurally the area was still almost unknown until the sledge journey by L. Koch in 1926-27. Koch (1929) described down-faulted Mesozoic blocks along the east coast and a down-faulted block with Jurassic sandstones resting direct on the Caledonian basement at the south coast. The coal-seams dis- covered by the 'Danmark Ekspedition' were studied in more detail by Frebold (1932). Then the Mesozoic areas were ignored until 1974, when the coal-bearing sequence was studied in detail by Clemmensen \& Surlyk (1976). In 1976 a Swedish-Danish expedition led by Christian Hjort, University of Lund, worked all over Hochstetter Forland. The main concern of this expedition was to study the Quaternary geology but in addition significant collections of Mesozoic fossils and rocks were made and a number of new localities were found. This new material forms the basis for the present account together with data collected by the author and Lars B. Clemmensen in 1974.

\section{Stratigraphy}

\section{Caledonian basement}

The flat and low-lying Hochstetter Forland is bordered to the west along a prominent fault-line by high, rugged mountains of the metamorphic 


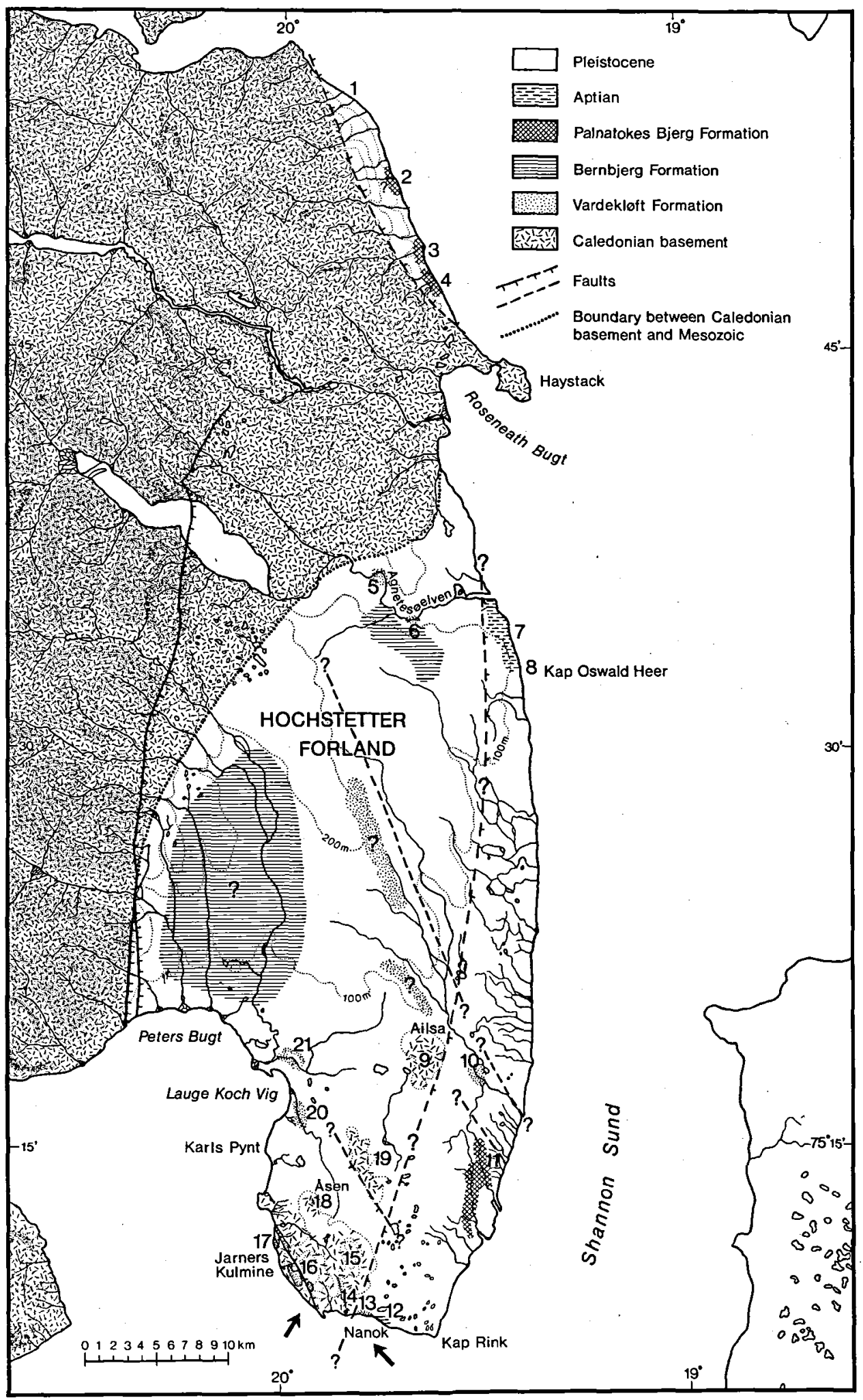

Fig. 1. Geological sketch map of Hochstetter Forland based on own observations and collections made by Hjort and others in 1976. 


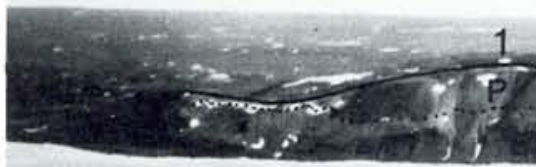

Negeren

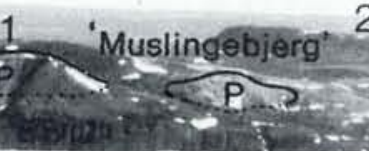

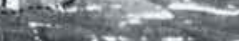

2
Fig. 2. The south-west coast of Hochstetter Forland. Oblique aerial photograph. View to the NE in the direction of the left arrow on fig. 1. The Callovian (?)-Upper Oxfordian Pelion

Caledonian basement which is composed mainly of biotite gneiss, migmatitic gneiss, mica schists and low metamorphic sediments of the late Precambrian Eleonore Bay Group. In Hochstetter Forland several outliers of Caledonian basement

Fig. 3. South slope of 'Sondre Muslingebjerg', south coast of Hochstetter Forland. The depositional nature of the contact be-
Member $(P)$ rests directly on the tilted peneplaned surface of the Caledonian rocks of the Eleonore Bay Group (EB). 1 ='Søndre Muslingebjerg', 2 = 'Nordre Muslingebjerg'.

occur, mainly belonging to the 'LimestoneDolomite Series' of the Eleonore Bay Group. The most prominent of these outliers constitutes the hills Søndre and Nordre Muslingebjerg at the southwest coast and Ailsa in south central Hoch-

tween the Pelion Member and the Caledonian rocks is clearly seen. Photo: Bjarne Leth Nielsen.

\section{'Søndre Muslingebjerg'}

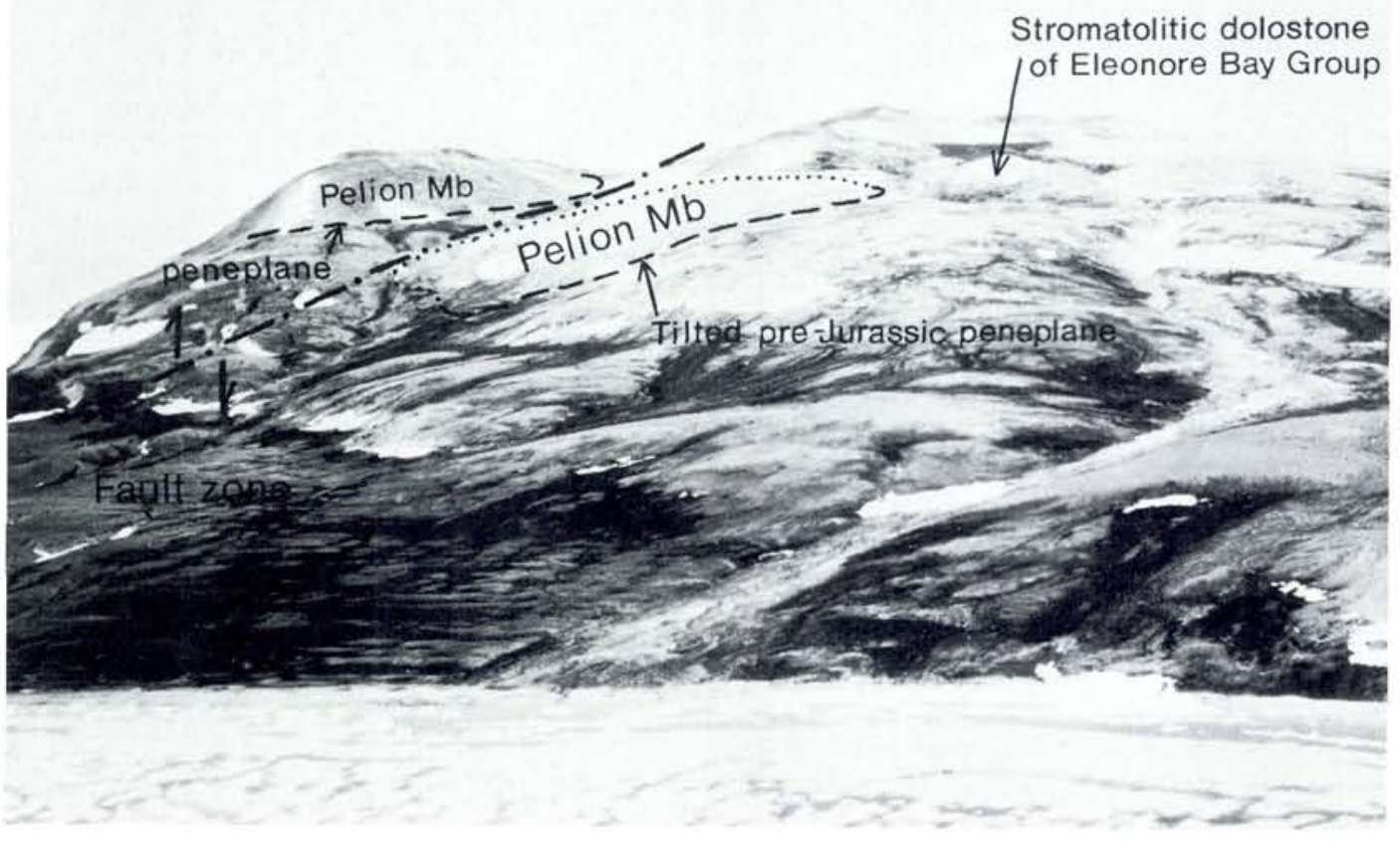




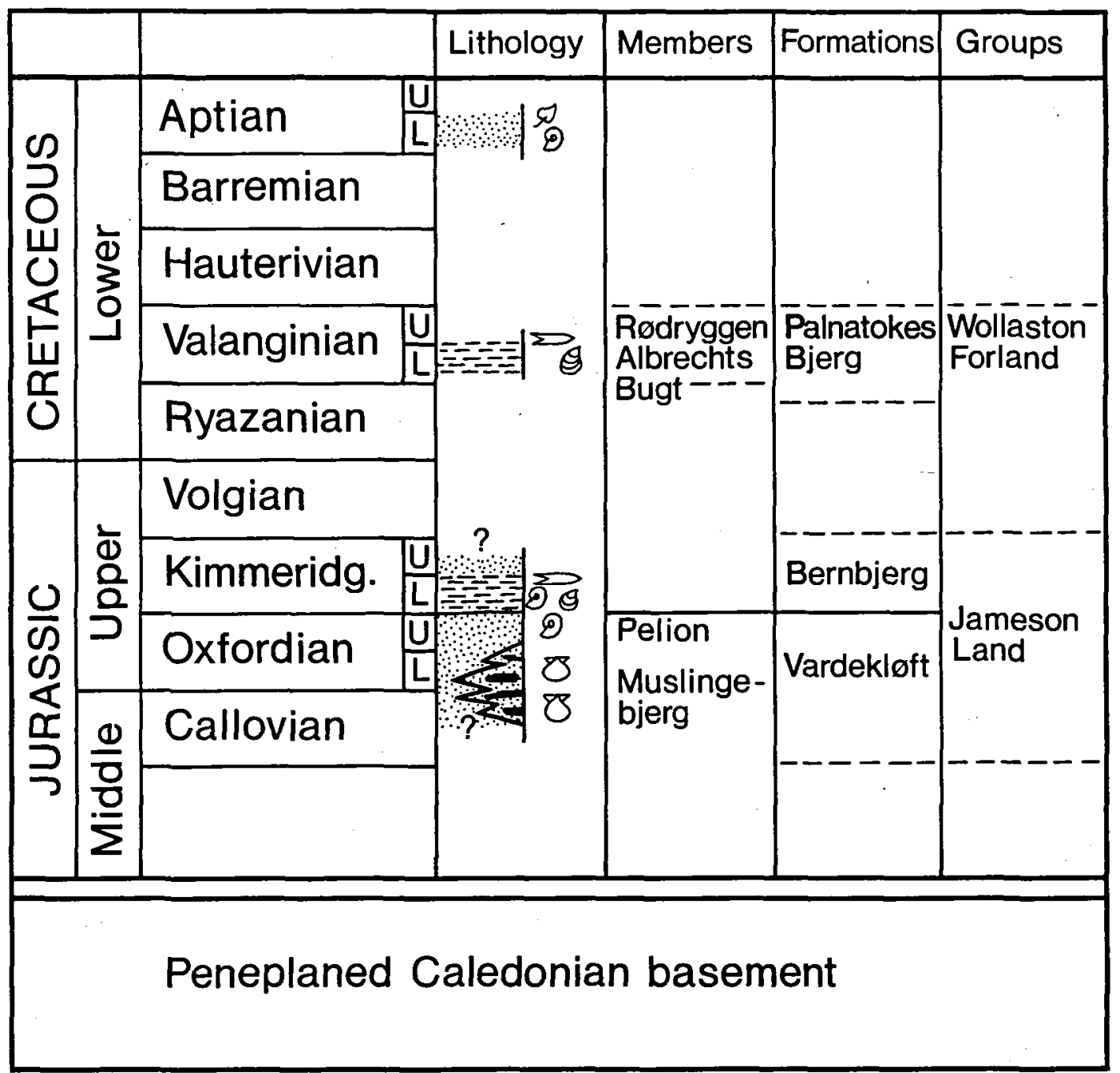

Fig. 4. Stratigraphical scheme of the Mesozoic sediments of Hochstetter Forland.

stetter Forland (figs 1, 2, 3). The geological map of Koch \& Haller (1971) shows too large an area of Eleonore Bay rocks east of the Muslingebjerg hills and likewise the Jurassic rocks are erroneously extended from the Søndre to cover also the Nordre Muslingebjerg. The mistake is due to a misinterpretation by Koch \& Haller of Frebold's sketch map from 1932 and to Frebold confusing yellow Jurassic sandstones with yellow Eleonore Bay stromatolitic dolostones (see fig. 3). Both mistakes are easily understandable for anyone familiar with geological work in these areas with their often poor or non-existent map material.

The Eleonore Bay rocks also crop out in seve- ral fault-blocks on the coast north of Jarners Kulmine and at Åsen (fig. 1). Block metamorphic shales occur northeast of Åsen, and on Ailsa a white granite was found by Hjorth (fig. 1).

\section{Jurassic}

All Jurassic rocks found in Hochstetter Forland were included in the Vardekløft and Bernbjerg Formations of the Jameson Land Group (fig. 4) by Surlyk (1977a).

?Callovian - Upper Oxfordian

Vardekløft Formation

The Vardekløft Formation is well exposed in the 
environs of Søndre Muslingebjerg on southwest Hochstetter Forland and along Agnetesøelven in the northernmost part of the Mesozoic area (fig. 1). Small scattered outcrops occur along the south and west coast. The formation contains two members in the area: Pelion and Muslingebjerg Members. The age relations of the members are not well known.

\section{Pelion Member}

The Pelion Member comprises white or light-yellow fine- to medium-grained quartz sandstones with subordinate horizons of coarsegrained or pebbly sandstones. On the south-east coast (loc. 10) a pebble conglomerate (fig. $5 b$ ) is overlain by a coarse-grained pebbly sandstone which again is followed by medium- to finegrained sandstone. The pebbles of the conglomerate are mainly composed of quartzite and it is probably a basal conglomerate resting on the peneplaned Caledonian basement. This boundary can be studied on Søndre Muslingebjerg although it is not well exposed (fig. 3 ). At locality 6 (figs 1 , 6) the top bed of the member is a $2.5 \mathrm{~m}$ thick green glauconitic fine-grained sandstone.

The sandstones appear structureless or show even, parallel and non-parallel lamination and planar or trough cross-bedding. Leaves, twigs and small logs are common, and plant detritus often forms thin flasers in otherwise homogeneous sandstones. Fossils, notably bivalves, serpulids and belemnites occur commonly, but are generally poorly preserved mainly as casts or imprints. A relatively diverse bivalve fauna has been collected on Søndre Muslingebjerg (Ravn 1911). Clemmensen \& Surlyk (1976) described a sequence from a narrow fault-block near Jarners Kulmine (fig. 1) comprising even parallel laminated medium-grained sandstone densely packed with large, undisturbed, more or less horizontally lying oysters. Upwards this dominantly monospecific assemblage becomes more diverse, but the bivalves (e.g. Isognomon groenlandicus (Ravn)) are mainly disarticulated and almost invariably orientated convex-upwards. Large Rhizocorallium burrows occur throughout this section. Field evidence suggests a position of this sequence immediately below and intertonguing with the Muslingebjerg Member, but the stratigraphic relations are not quite clear. It is suggested that the Muslingebjerg Member intertongues with the lower parts of the Pelion Member and the boundary is defined by the appearance of the prominent coal-seams of the Muslingebjerg Member.

The top beds of the member on Søndre Muslingebjerg contain Amoeboceras cf. hunningtonense Wright and Amoeboceras sp. nov. Ravn (1911: 11, pl. 35) indicating a late Oxfordian $A$. glosense or A. serratum Zone age (see Sykes \& Surlyk 1976: 429, who mentioned these species under the general description of the Muslingebjerg Member).

The lower beds of the member are not dated but might still be of a Middle Jurassic Callovian Age.

The best exposed Pelion Member locality is the south side of Søndre Muslingebjerg. The member is furthermore found on the north side of Søndre Muslingebjerg, along the west coast in Lauge Koch Vig and in Peters Bugt (Frebold 1933), and in small fault bounded outliers on the south coast west of Nanok. An isolated locality is situated 3.5 $\mathrm{km}$ east of Ailsa (loc. 10), and along Agnetesøelven several good outcrops occur (loc. 5 \& 6). Large parts of the central Hochstetter Forland plateau are probably composed of Pelion Member sandstones immediately below the Pleistocene cover.

\section{Muslingebjerg Member}

The sedimentology of the type section of the Muslingebjerg Member at Jarners Kulmine (fig. 1) was described in detail by Clemmensen \& Surlyk (1976).Sykes \& Surlyk (1976) studied the age relations of the sequence, but did not distinguish clearly between the Pelion and the Muslingebjerg Members; the Muslingebjerg member and its boundaries towards the Pelion Member were first defined precisely by Surlyk (1977).

Eight facies of the member were recognized by Clemmensen \& Surlyk (1976). Facies 8 of Clemmensen \& Surlyk (1976) which comprised parallel laminated sandstone dominated by bivalves is here referred to the Pelion Member. The seven remaining facies comprise: 1) Autochthonous coal forming 2-3 m thick beds. 2) Laminated mudstone with coal, up to $2 \mathrm{~m}$ thick. 3) Silty, parallel laminated sand with coal partings, $2 \mathrm{~m}$ thick. 4) Greyish, fine-grained faintly parallel laminated sand reaching $4 \mathrm{~m}$ in thickness. 5) Light, fine- to medium-grained, parallel laminated 


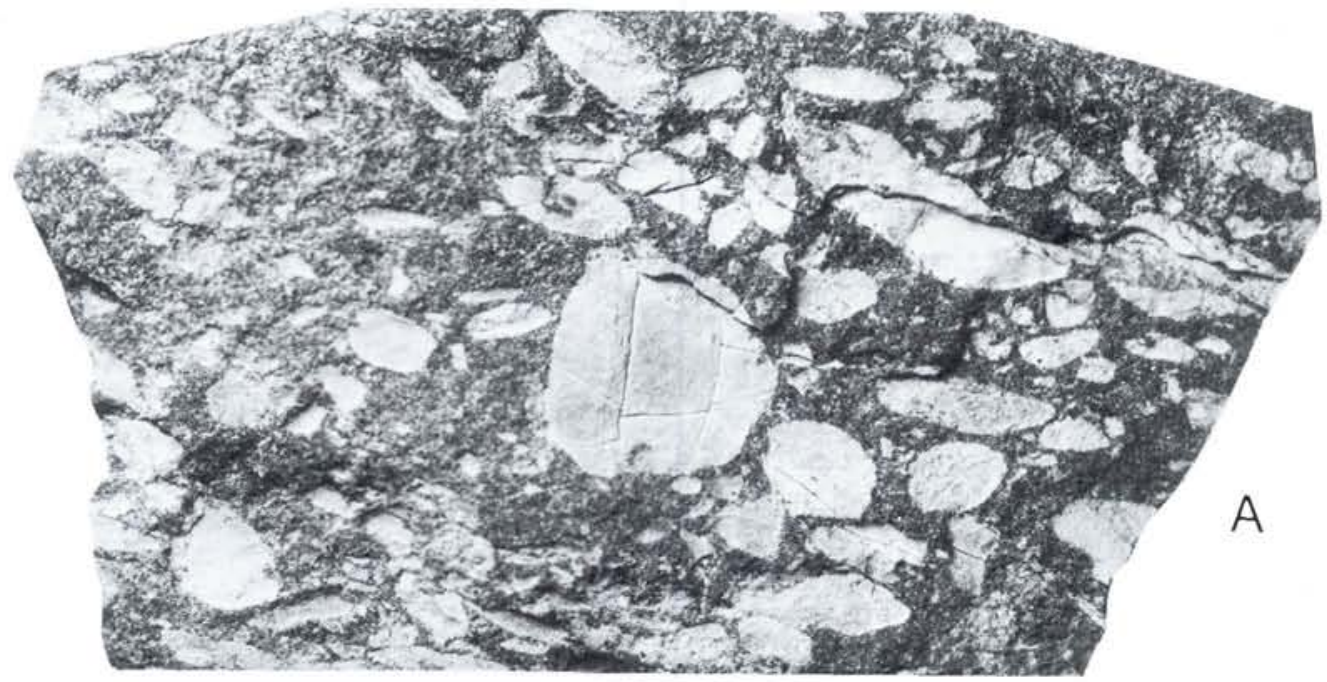

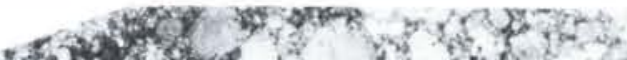

as

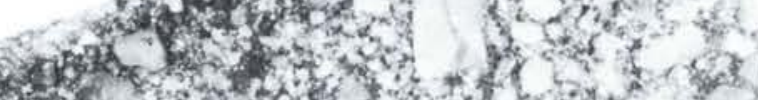

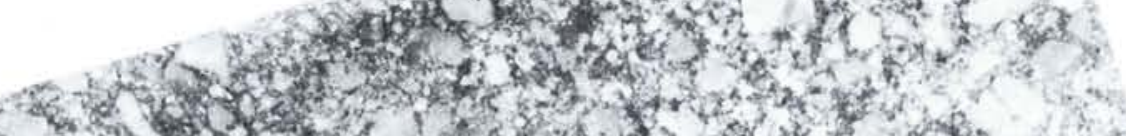

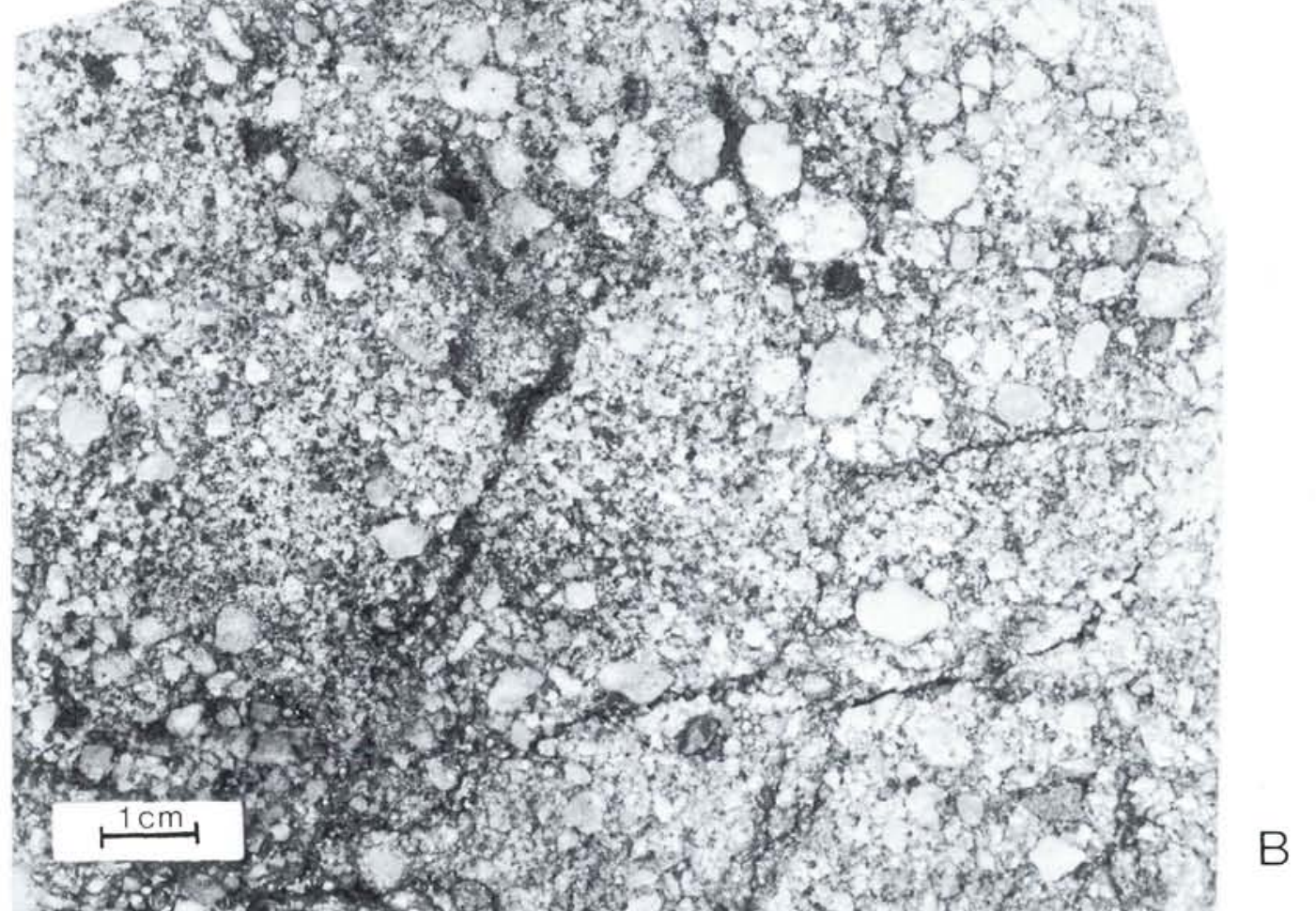

Fig. 5. A. Matrix supported conglomerate with rounded clasts of light grey mudstones formed by erosion of lithified Albrechts Bugt Member. The conglomerate was probably deposited from a subaqueous debris flow and is thought to be almost contempora- neous with the clasts. Locality 4, north-eastern Hochstetter Forland.

B. Pebble conglomerate of the presumed basal Pelion Member. Locality 10 (fig. 1). 
sand, about 3-5 $\mathrm{m}$ in thickness. 6) Pebbly, mainly low-angle cross-bedded sand, $2 \mathrm{~m}$ thick. 7) Pebbly structureless sand up to $2 \mathrm{~m}$ thick.

The facies occur in two slightly different facies associations. The first association comprises a lower upwards coarsening unit followed by an upper upwards fining unit topped by a coal-seam. The lower portion was interpreted as being caused by the landward migration of a barrier-lagoon system during net sedimentation resulting in a sequence of inner and outer lagoonal deposits overlain by deposits from the near-shore zone. The upper portion of the sequence might be the result of a seawards migration of the described depositional system causing supratidal beach deposits and later swamp sediments to be deposited upon the intertidal beach sediments. The second association comprises faintly laminated sand with pebbly horizons overlain by a coal-seem. This association may denote the more landward portion of a seaward-migrating barrier-lagoon environment where occasional storm activity resulted in the deposition of the more coarse-grained sediments.

The transition between the Muslingebjerg and the Pelion Member at loc. 17 contains a shallow water bivalve fauna which includes Camptonectes broenlundi, Quenstedtia gibbosa, Buchia concentrica, 'Cucullaea' contracta and Isognomon groenlandicus (Sykes \& Surlyk 1976: 429). This fauna is, in part, well known from the Upper Oxfordian Kløft I Formation on Store Koldewey (Ravn 1911; Sykes \& Surlyk 1976).

The Muslingebjerg Member occurs in a narrow NW-SE orientated fault-block on the south-west coast of Hochstetter Forland. Hjort observed abundant loose lying coal fragments of the same type as at Jarners Kulmine along the middle and lower reaches of Agnetesøelven in the northern part of the Mesozoic area (fig. 1).

\section{Lower Kimmeridgian}

Bernbjerg Formation

The Bernbjerg Formation (Surlyk 1977a) overlies the sandy Vardekløft Formation with a relatively sharp contact. It is only exposed in small often tectonically disturbed outcrops, and little is therefore known about the thickness. At locality 6 at Agnetesøelven (figs 1,6 ) the thickness is at least some tens of metres.

The formation mainly comprises dark, parallel
Loc. 6

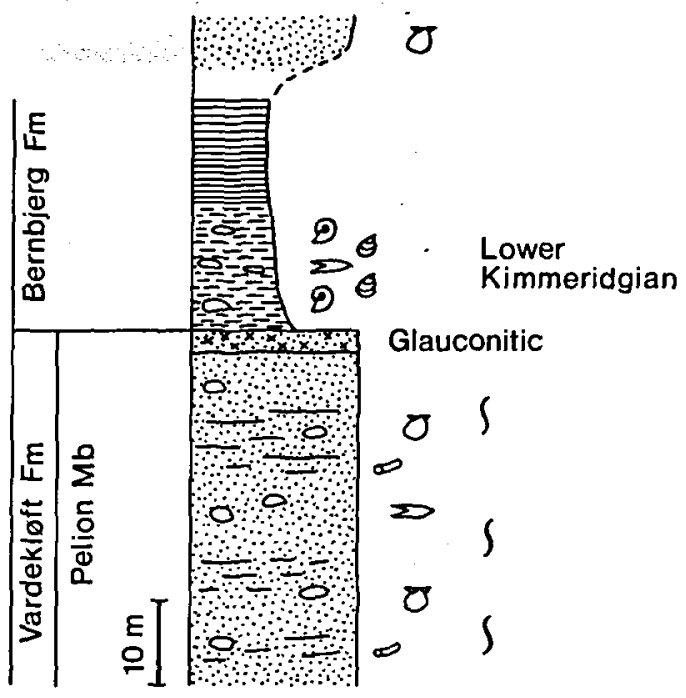

Fig. 6. Section of the Pelion Member and the Bernbjerg Formation, locality 6, Agnetesøelven, Hochstetter Forland (measured by Hjort 1976). Thicknesses can only be roughly indicated owing to poor exposure.

laminated silty mudstones, and fine sandy mudstones, which may display lenticular and wavy lamination. It is coarser grained and was deposited under more near-shore and better aerated conditions than in Kuhn $\varnothing$ and Wollaston Forland (Surlyk 1977a, Surlyk \& Clemmensen, in press). At locality 6 (figs 1,4 ) the formation shows an upwards increase in grain-size from silty mudstone to sandstone probably reflecting a prograding coastline.

Ammonites, small bivalves and belemnites occur in great abundances. Plant remains varying from finely comminuted debris to logs several metres long are characteristic constituents.

The upper boundary of the formation is nowhere exposed, but younger strata include light grey and red mudstones with calcareous concretions of the Valanginian Albrechts Bugt and Rødryggen Members. By analogy with the relations immediately to the south on the east coast of Kuhn $\varnothing$ these members probably rest on the Bernbjerg Formation with slight angular unconformity (Surlyk \& Clemmensen 1975; Surlyk 1975a, b, 1977a).

The formation is exposed in scattered outcrops throughout Hochstetter Forland: in a small fault-block on the extreme south coast east of 
Nanok (loc. 12), in the western areas north of Peters Bugt, and to the north around Agnetesøelven (loc. 6) (fig. 1).

Frebold (1933) figures ammonites of Early Kimmeridgian Age preserved in sandstones (Sykes \& Surlyk 1976) and the new collections by Hjort and others include Early Kimmeridgian Aulacostephanus mutabilis Zone faunas from a locality east of Nanok (loc. 12) and from loc. 6 at Agnetesøelven (figs 1, 4).

The fauna from the first locality (fig. 7a, b, c) includes Amoeboceras (Amoebites) cricki, Amoeboceras (Amoebites) sp., Palaeonucula sp., Grammatodon sp., Trautscholdia sp., Coelastarte sp. and Buchia concentrica, whereas the fauna from the Nanok locality comprises Amoeboceras (Amoebites) cf. mesezhnikovi, Amoeboceras (Amoebites) sp., Aulacostephanus (Xenostephanus) cf. groenlandicus, $A$. (Xenostephanoides) sp. and Buchia concentrica.

\section{Cretaceous}

Valanginian

Albrechts Bugt and Rødryggen Members

Valanginian sediments have previously not been recorded from Hochstetter Forland. Bruch and Mikaelsson, members of Hjort's expedition in 1976 succeeded, however, in finding a section in a river 8-10 km SE of Ailsa (loc. 11) exposing strata of the Albrechts Bugt and Rødryggen Members of the Valanginian Palnatokes Bjerg Formation (Surlyk 1978; see also Surlyk \& Clemmensen 1975).

The lower $20 \mathrm{~m}$ of the sequence comprise relatively coarse-grained grey mudstones with $0.5-1$ $\mathrm{m}$ thick beds of siltstone - fine sandstone rich in belemnites and bivalves. These beds are overlain by grey fossiliferous calcareous mudstone weathering to a red colour and in places passing into fully red calcareous mudstone. The whole sequence dips $10^{\circ}$ towards the east.

The bivalves of the mudstones consist of $\mathrm{Bu}$ chia keyserlingi (fig. 7e, f) which date that part of the sequence to the Lower Valanginian. The lithological description suggests that the mudstones and grey limestone can be safely grouped in the Albrechts Bugt Member of Surlyk (1978) and that the $0.5-1 \mathrm{~m}$ coarser beds are turbidites (compare Surlyk \& Clemmensen 1975). The red mudstones belong to the Rødryggen Member of Surlyk (1978) or to the transition from the Al- brechts Bugt to the Rødryggen Member. The sequence is thus almost identical to the contemporaneous strata immediately to the south on the east coast of Kuhn $\varnothing$.

On the northern part of the east coast $12 \mathrm{~km}$ north of Haystack (loc. 3, fig. 1) an assemblage of loose blocks of fine-grained sandstones contain somewhat doubtful specimens of Buchia keyserlingi. If the determination is correct, these sediments probablybelong to the coarser parts of the Albrechts Bugt Member or the transition to the Young Sund Member of Surlyk (1978).

Close to this locality a sequence more than 20 $\mathrm{m}$ thick was found by Hjort in 1976 (loc. 4, fig. 1). From below, the section comprises laminated sandstone overlain by sandstone with slump structures, clay galls and plant fragments (fig. 5). This is followed by greyish yellow sandstone with thin coaly horizons. Photographs and samples of the sequence suggest deposition from turbidity currents and other sediment gravity flows and the sequence might belong to the sandy parts of the Valanginian Albrechts Bugt Member or to the transition to the Young Sund Member, but an Aptian-Albian age cannot be totally excluded. The rock types are, however, unknown from the East Greenland Jurassic.

\section{Aptian}

Sediments of Aptian age have not previously been recorded from Hochstetter Forland, but Hjort succeeded in finding sandstones with an ammonite fragment here determined with some hesitation as Deshayesites deshayesi (d'Orb.) (fig. 7d) at a locality between the mouth of Agnetesøelven and Kap Oswald Heer on the east coast (loc. 7 fig. 1). This indicates the presence of Lower Aptian (Zones of $D$. forbesi or $D$. deshayesi).

The ammonite was found in the basal part of a $25 \mathrm{~m}$ thick upwards coarsening sequence which begins with $10 \mathrm{~m}$ of silt- and sandstone showing cross-bedding, coaly flasers and shrinkage cracks. the sandstone contains ammonites, gastropods and abundant plant fragments. After an unexposed $5 \mathrm{~m}$ interval it is followed by $10 \mathrm{~m}$ of very coarse apparently structureless quartz sandstone.

In the first larger stream south of loc. 7 another locality was found which might also be of Aptian age (loc. 8 fig. 1). The sequence is $25 \mathrm{~m}$ thick, 

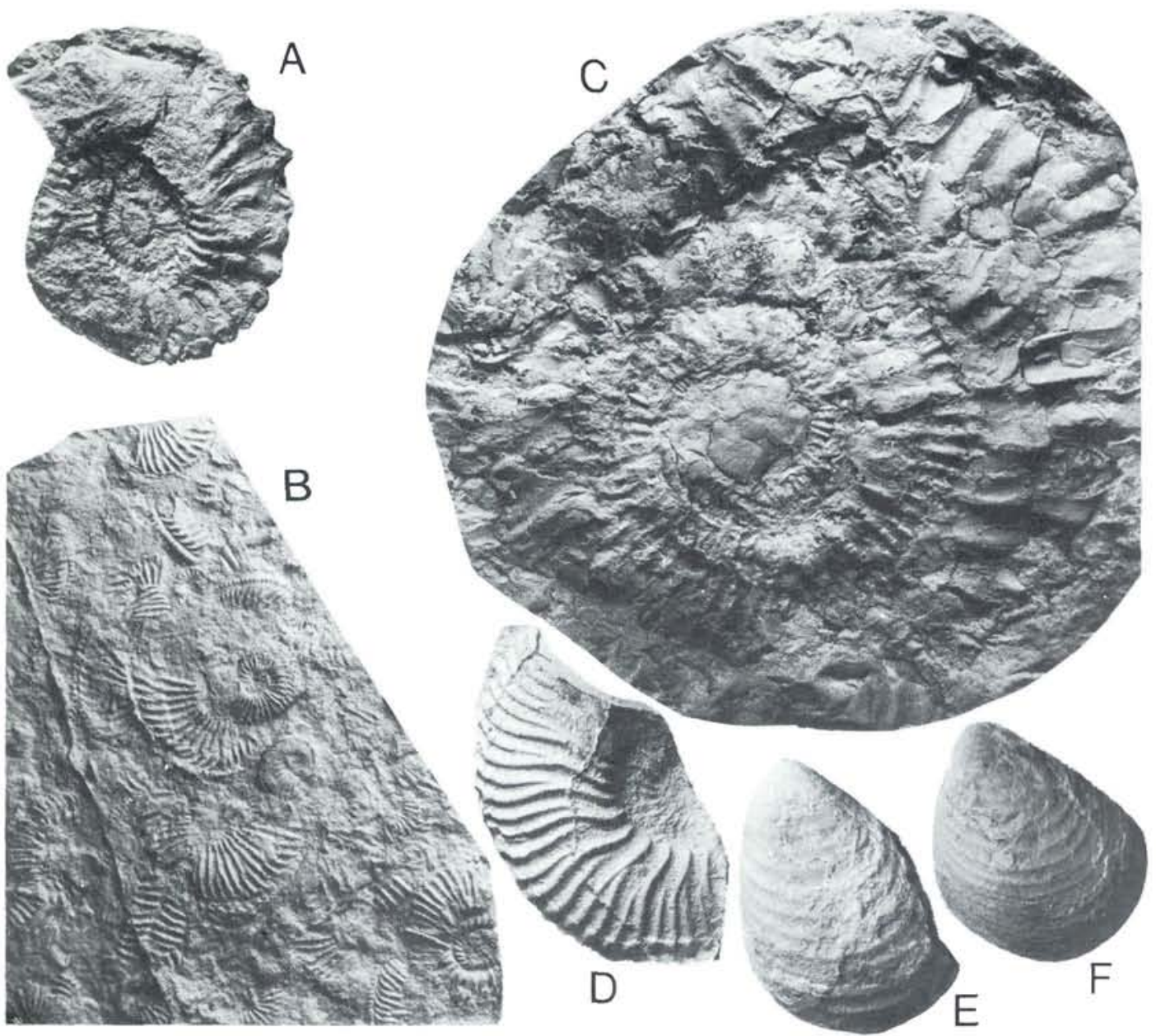

Fig. 7 A. Amoeboceras (Amoebites) cf. mesezhnikovi Sykes \& Surlyk. Loc, 12 (fig. I). Lower Kimmeridgian.

B. Amoeboceras (Amoebites) cricki (Salfeld). Loc. 12 (fig. 1). Lower Kimmeridgian.

C. Aulacostephanus (Xenostephanus) cf. groenlandicus Ravn. Loc. 12 (fig. 1). Lower Kimmeridgian.

upwards fining and comprises sandstone and thin siltstone with clay galls and coaly flasers grading upwards into silt- and mudstone. No fossils were found in the locality so the Aptian age is only suggested by the general character of the sediments together with the position of the locality a few $\mathrm{km}$ south of the Lower Aptian sediments of loc. 7.

The Aptian strata comprise the youngest pre-Pleistocene rocks until now recorded from Hochstetter Forland. Along the eastern coast north of Haystack several small undated localities were found in the narrow down-faulted
D. Deshayesites deshayesi (d'Orb.). Loc. 7 (fig. 1). Lower Aptian.

E-F. Buchia keyserlingi (Lahusen). Loc. 3 (fig. 1). Lower Valanginian.

coast-parallel block. Only one of the localities (loc. 3, fig. 1) has been dated to the Lower Valanginian and the remainder is most probably Valanginian as judged by facies. A Jurassic age can be excluded, whereas an Aptian-Albian age still remains a theoretical possibility.

\section{Structures}

The very flat and low-lying nature of the area, the almost total Pleistocene cover, and the small size 
of the outcrops precludes detailed mapping of faults.

Only the western border fault stands out clearly as a major topographic line separating the more than $1000 \mathrm{~m}$ high Caledonian area to the west from the Mesozoic lowland to the east. Rapid lateral changes in dip direction and close situation of Mesozoic rocks of different ages in many small river and coastal sections suggest, however, that also the Mesozoic low-lying area is dissected by faults. The c. $400 \mathrm{~m}$ high hills of Søndre and Nordre Muslingebjerg to the SW comprise Calodonian basement surrounded on all sides by down-faulted Mesozoic rocks and positions of some of these faults can be mapped directly in the field.

Study of aerial photographs proved to be of little or no value in the study of faults, whereas close inspection of Satellite Images revealed the presence of several systems of lineaments. When plotted on the geological map, some of these lineaments may be interpreted as representing faults as they are situated between localities of different ages. Furthermore, the majority of the larger rivers on the east coast runs in their main course parallel with a distinct set of NNW-SSE trending lineaments.

The general strike and dip directions in the least disturbed Hochstetter Forland localities are almost identical to those of Kuhn $\varnothing$ where Mesozoic geology and structures are well known (Vischer 1943; Maync 1947, 1949; Surlyk \& Clemmsensen 1975; Surlyk 1977a, 1978). The areal distribution of the different formations is also generally the same in the two areas. The Jurassic Vardekløft and Bernbjerg Formations are mainly found in the western parts of Hochstetter Forland and dip towards SW, whereas the Valanginian Palnatokes Bjerg Formation and the Albian rocks occur in a down-faulted position along the east coast.

The western border fault is a direct northwards continuation of the Thomsen Land Fault (Vischer 1943; Koch \& Haller 1971). The more eastwards situated Kuhn Fault has by analogy been extrapolated northwards by Koch \& Haller (1971) to follow the east coast of Hochstetter Forland approximately $3.5 \mathrm{~km}$ inland to a point south of Kap Oswald Heer where it crosses the coastline. The misinterpretation of Frebold's (1932) map by Koch \& Haller (1971) resulted in the Eleo- nore Bay Group being extended too far east of the Muslingebjerg hills. The Kuhn Fault should therefore rather cross the south coast more westwards about $1 \mathrm{~km} \mathrm{~W}$ of Nanok and continue northwards to the mouth of Agnetesøelven as shown on fig. 1. The Mesozoic strata east of the fault dip towards SE, E and NE but the observations are only few in number. Since the oldest Mesozoic units are exposed immediately to the east of the fault and the younger units appear further to the east, it is not necessary to introduce any N-S trending faults east of the Kuhn Fault. The Kuhn Fault is cut by several NNW-SSE faults as already noted by Sommer (1957). The most well-defined of these delimit the Eleonore Bay rocks of the Muslingebjerg hills from the surrounding Mesozoic sediments.

The age of the different fault systems is only little known. The main western border fault was undoubtedly active throughout the Jurassic and Cretaceous times where it formed the actual western coastline (Koch 1929; Vischer 1943; Surlyk 1977a, b 1978).

The Kuhn Fault was initiated in the early Valanginian during the Volgian-Valanginian tectonic phase of antithetic block faulting (Surlyk 1978). The condensed Rødryggen red beds which occur over and adjacent to the fault are elsewhere restricted to structural highs. This suggests, however, that the throw along the fault was relatively small and the structure was probably more like a monocline without any exposed fault-scarp.

The initiation of the coast parallel border fault north of Haystack cannot be dated. All sediments exposed along it seem to be of early Cretaceous age and the fault is thought to have been initiated in the Valanginian. The throw was probably relatively large resulting in the formation of a partly subaqueous fault-scarp along which a series of coalescent submarine fans was formed (compare Surlyk 1978).

The NNW-SSE trending cross faults are more difficult to date. Sommer (1957) noted that the system was of Caledonian origin and was reactivated in Mesozoic and post-Mesozoic times. The faults are part of a major NNW-SSE or NW-SE trending system which can be traced throughout the Mesozoic basin of East Greenland (Surlyk 1977b). It was active in a series of well dated episodes throughout the Jurassic (Sykes \& Surlyk 


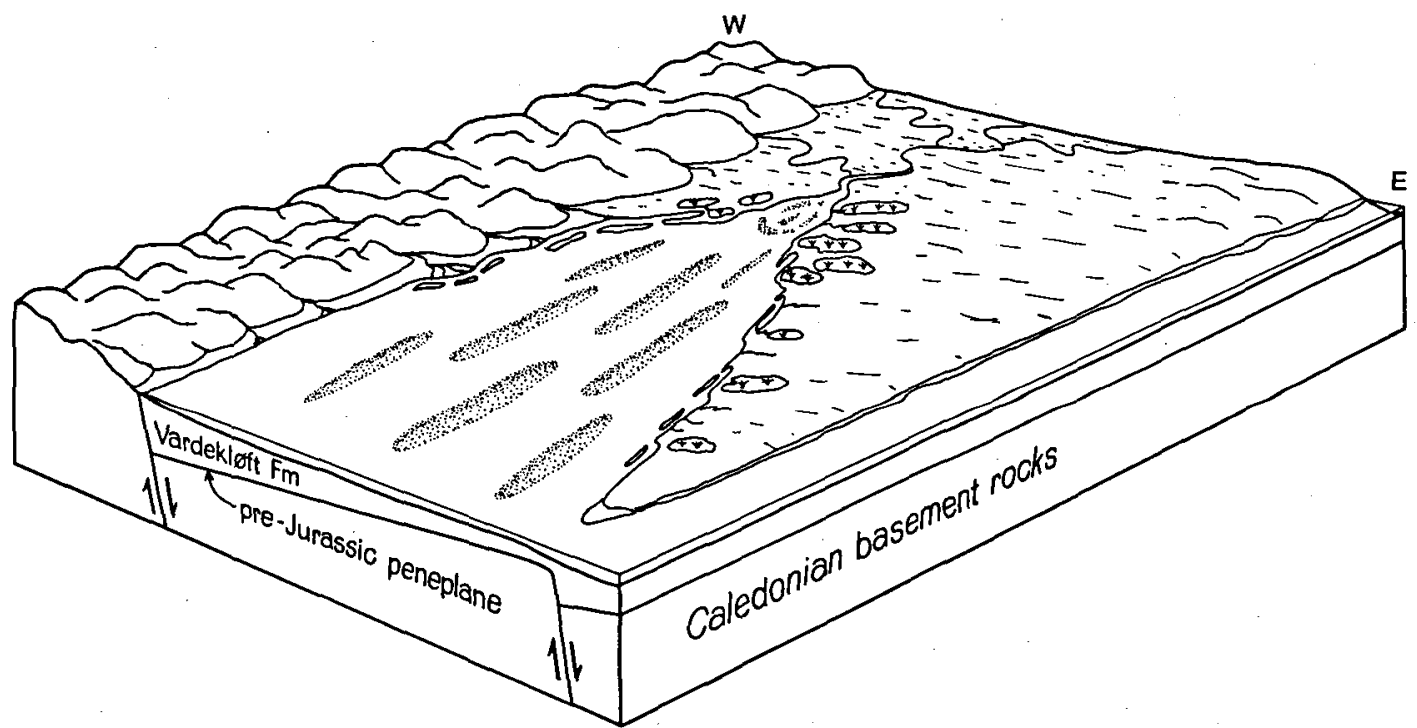

Fig. 8. Palaeogeographic reconstruction of the Hochstetter Forland area in Oxfordian times illustrating the tidal and wave influenced delta prograding southwards into a narrow trough. Coal-bearing sandstones of the Muslingebjerg Member were deposited in lagoons behind wave formed barriers whereas shallow marine sandstones of the Pelion Member were deposited in

1976; Surlyk 1977a, b, 1978) and this was probably also the case in Hochstetter Forland.

\section{Palaeogeographic evolution}

The Caledonian basement of the area now constituting Hochstetter Forland underwent peneplanization in pre-Jurassic times. At the Middle-Upper Jurassic boundary it was transgressed for the first time and the coarse-grained Pelion sandstones were laid down with a basal conglomerate directly on the basement. The environment seems to have been one of mainly southwards migrating dune and sand wave fields in a very shallow marine bay (figs $8-10$ ). This was limited to the west by the main border fault and to the east by the elevated crest of the Hochstetter Forland block. The precise location of the eastern border fault is not known but by analogy with W-E cross sections through Wollaston Forland and Kuhn $\varnothing$ to the south (Visher 1943) it is thought to lie somewhere between the east coast of Hochstetter Forland and the island of Shannon. To the north the limit of the bay was probably formed by the gently south or south-westwards tilted dip slope foreshore, shoreface and shallow shelf environments. The tidal ridges are highly speculative in this area and are mainly based on the shape of the basin, facies types, transport directions, and inferred tidal action. Width of the block on figs $8-10$ is of the order of $30-50 \mathrm{~km}$.

of the basement block as no fault has been detected here.

The normal to restricted marine dune fields of the Pelion Member in periods of strong progradation gave way to barriers and lagoonal coal-forming swamps of the Muslingebjerg Member (fig. 8) (Clemmensen \& Surlyk 1976).

In Early Kimmeridgian times a rapid fault-controlled submergence resulted in an abrupt facies change to the dark sandy Bernbjerg mudstones (fig. 9). This tectonic phase can also be demonstrated to the south on Kuhn $\varnothing$ (Sykes \& Surlyk 1976).

The degree of submergence and subsidence was, however, small compared to the more southern blocks. This is revealed by the Bernbjerg Formation being much thinner, coarser grained and containing a more diverse fauna of benthic animals. The formation furthermore shows signs of progradation in the form of rapid coarsening-upwards from black mudstones to relatively coarse-grained sandstone (fig. 6 ). The more distal southern blocks on the contrary contain very thick monotonous sequences of black mudstones with little or no indication of progradation of the coastline. 


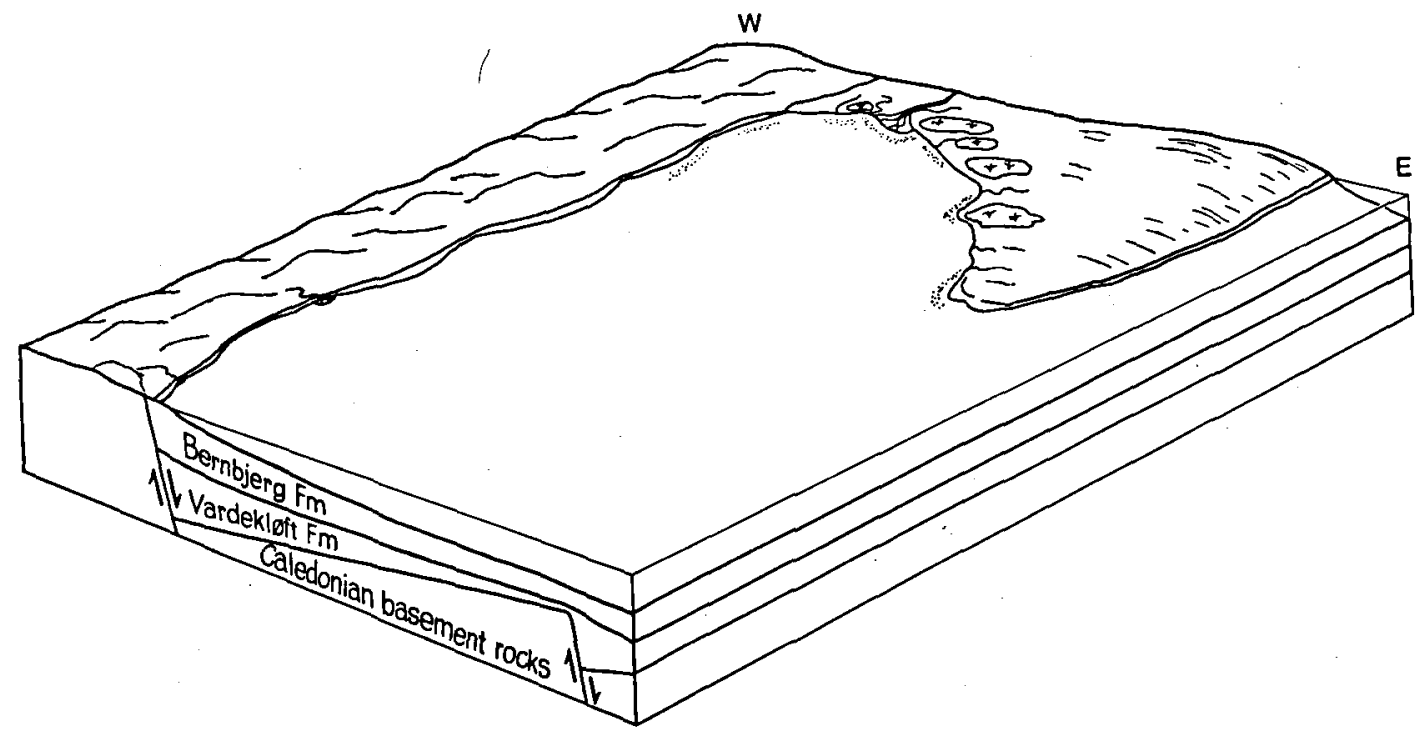

Fig. 9. Palaegeographic reconstruction of the Hochstetter Forland area in early Kimmeridgian times. The main part of the area was dominated by deposition of shallow marine offshore mudstone with fine sand and silt storm layers deposited generally

This depositional regime of a muddy shelf showing influence of progradation especially in the more proximal northern part of the bay was terminated by the very strong phase of antithetic block faulting in Volgian-Valanginian times (Vischer 1943; Maync 1947; Surlyk 1978).

The Valanginian light grey and red mudstones on the east coast are identical to those of the Wollaston Forland - Kuhn $\varnothing$ area where they were interpreted as a condensed association located over submerged uptilted block crests or small horsts (Surlyk 1978b). The facies association is known from almost all of East Greenland except for Jameson Land where the faulting was simple and not antithetic, and where the resulting sediments are coarse-grained shallow marine sandstones (Surlyk 1973, 1975b).

By analogy then the Hochstetter Forland area fragmented and collapsed in Volgian-Valanginian times and submarine fans were formed along the western border fault (fig. 10). The fan sediments are now removed by erosion in the main part of Hochstetter Forland and only the condensed crestal sequence is preserved in a down-faulted position on the east coast. To the north the border fault is shifted eastwards en-echelon and the coarse-grained submarine fan sediments are here found in a few localities in the narrow coast parallel down-faulted block (loc. 3 below wave base from storm generated suspensions. The northern coastline prograded slowly to the south enclosed between the western borderland and eastern crestal area of the block which formed an emerged/submerged oceanographic shoal.

\& 4 fig. 1). The dating is not very good but the rock types are closely related to the Valanginian fan sediments described from Wollaston Forland (Surlyk, 1978).

The Hauterivian-Barremian seems to be absent and probably represents a period of emergence as envisaged for the rest of East Greenland (Maync 1949). The record of the following Aptian Stage is very fragmentary but Hochstetter Forland seems to have been submerged once again and relatively coarse-grained shallow marine sediments were laid down. Nothing can be said about the more detailed depositional environment and palaeogeography of the Aptian Stage.

\section{Evolution of the Jurassic basin of East Greenland}

The Mesozoic sediments of East Greenland were interpreted by Surlyk (1977a, b) as deposited in a rifted basin which might represent a preCretaceous 'failed arm' of a triple junction centred south of Scoresby Sund. The rifting took place in a series of steps by progressive down faulting from south to north. The rift basin in plan has an oblong triangular wedge shape being widest to the south and narrowing to the north. The individual fault-blocks are likewise consecu- 


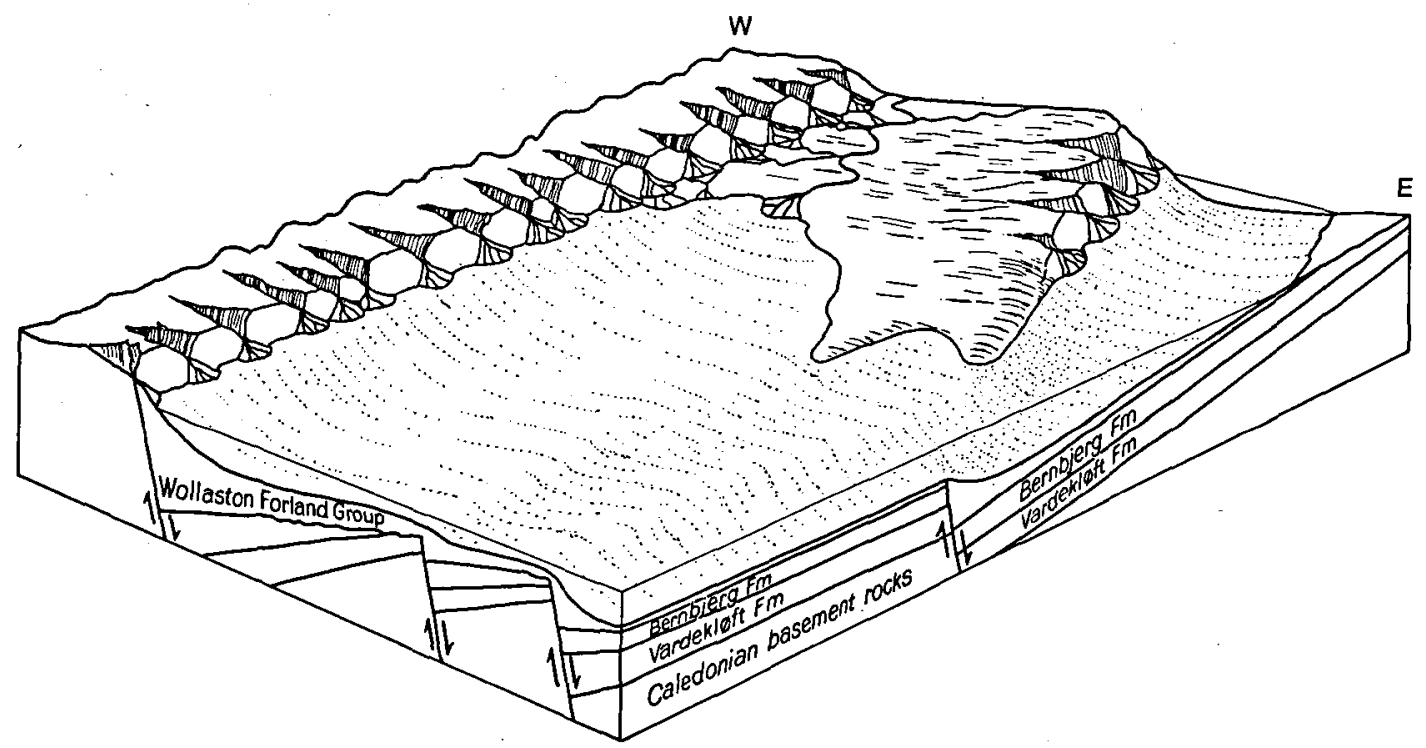

Fig. 10. Palaeogeographic reconstruction of the Hochstetter Forland in Valanginian times. Faulting accompanied by rotation of blocks resulted in the formation of coalescent submarine fans along the scarps. Fan deposits include conglomerates and coarse sandstones deposited by a variety of sediment gravity flows. Over the crestal area of the block were deposited condensed grey and red mudstones. tively narrower from south to north. The central and southern blocks were submerged first followed by those immediately to the west, east and north as shown in the model on fig. 11. The first block was submerged by the Jurassic transgression in the Hettangian-Pliensbachian, the second group of blocks in the Bathonian, the third group in the ?Callovian, and the fourth group in the Oxfordian.

Eastern Store Koldewey is the northernmost exposed Mesozoic block and Hochstetter Forland follows immediately to the south down the rift. None the less Store Koldewey was submerged already in the Bathonian, whilst the general mid-Jurassic transgression first reached Hochstetter Forland at the Middle-Upper Jurassic boundary. This is in agreement with the model in fig. 11 because Store Koldewey occupies a position in or close to the axis of the rift whereas Hochstetter Forland has a more lateral position.

The Jurassic-Lower Cretaceous sequence of East Greenland thus represents a series of transgressions during which larger and larger parts of the area became submerged in a series of steps. The actual deposits were almost all laid down as a result of progradation from north to south. All the coarse clastic units were thus transported down the axis of the rift and consequently the most 'proximal' facies types are found to the north on each block. Individual lithostratigraphic units also became more 'proximal', thinner, and younger when passing from one block to the next northern block.

The only exceptions to this general pattern are the extremely coarse clastic submarine fan sediments which were deposited along and away from fault-scarps on tilted fault-blocks in Volgian-Valanginian times (Surlyk 1975a, b, 1978). In this case the transport is lateral in respect of the main rift (Surlyk 1978).

The longitudinal north to south transport and the more 'proximal' nature of the sediments on the northern blocks also fit well with the interpretation of the Jurassic basin as representing a 'failed arm' (compare Burke \& Dewey 1973).

'Failed arms' were thus postulated by Dewey \& Burke (1974) to have funnelled the sediment from the continent and allowed major deltas to form.

The model presented here for the Jurassic basin evolution and sediment transport patterns may also be applicable for other parts of the northern North Sea and the margins of the Norwegian-Greenland Sea. The model predicts: 1) Lateral facies changes are pronounced in a direction parallel to the main fault zones owing to the 


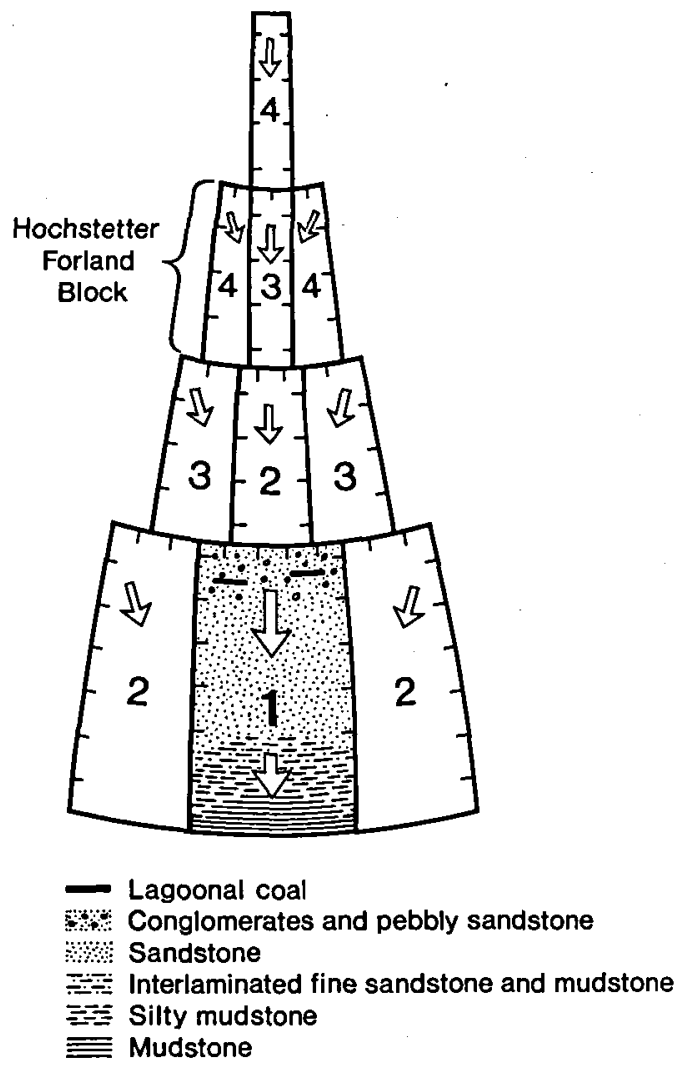

Fig. 11. Very schematic model of the Jurassic rift basin of East Greenland. Rifting took place from south to north by progressive down-faulting in a series of steps as indicated by the numbers on individual fault-blocks. The relative position of the Hochstetter Forland block is indicated. The arrows show the general direction of basin filling for all shallow marine Jurassic sandstones. Middle Jurassic facies distribution pattern of the individual blocks indicated on block number one.

longitudinal transport. 2) Each major sand body shows one or more coarsening upwards trends. 3) Lateral facies changes transverse to the structural grain are relatively unimportant. 4) Abrupt vertical changes to deeper water facies. 5) Stepwise thinning of individual units and of the whole sequence takes place in a longitudinal direction.

If the general aspects of the model are correct the geological and in particular the economic implications are obvious. The Middle Jurassic more or less lobate deltas envisaged by Kent (1975, fig. 6) for the northern North Sea may actually be linear, oblong rift parallel sheets of prograding sandbodies and the Middle Jurassic oil fields of the Brent province (Bowen 1975) may have source areas at the end of the graben system and not on the shoulders. Furthermore the sediments may have been transported along the graben resulting in generally longitudinal facies changes. This can be tested by studying grain size changes and systematic changes in thickness and stratigraphical completeness from one fault-block to another in a graben parallel direction. If such trends are observed the thickest and most complete sequence according to the model should characterize the most distal block. The grain sizes should increase in the proximal direction on each block and from block to block for the same chronostratigraphical unit.

Acknowledgements. Christian Hjort and his colleagues Lena Adrielsson, Hans Bruch and Jan Mikaelsson from Lund, Sweden, are thanked for placing samples of rocks and fossils from Hochstetter Forland at my disposal. D. V. Ager (Swansea, U.K.) read the manuscript critically. R. M. Sykes (Assen, the Netherlands) assisted in determining the Kimmeridgian ammonites. A. Brantsen did the typing, S. L. Jakobsen the photography, and C. Rasmussen the drafting. The paper is published with the permission of the Director of the Geological Survey of Greenland.

\section{Dansk sammendrag}

Hochstetter Forland er strukturelt opbygget af flere sydvestligt og vestligt hældende forkastningsblokke, der er begrænset af et omtrent nord-syd strygende hovedforkastningssystem og et system af nordvest-sydøst strygende tvarforkastninger. Det lithostratigrafiske skema, der bruges i de øvrige dele af det ostgrønlandske Mesozoikum er udstrakt til også at gælde Hochstetter Forland og kun et nyt led er blevet opstillet specielt for sedimenter på denne halvø. Alle enheder er grovere, tyndere og relativt yngre end umiddelbart mod syd på Kuhn $\emptyset$.

Det sandede lavtvandet marine Pelion Led af Mellem(?) $\emptyset$ vre Jura alder ligger direkte på peneplaniserede Kaledoniske bjergarter. Leddet indledes med et basalkonglomerat og er lateralt veksellejret med det kulførende og sandede lagunale lavt vandet marine Muslingebjerg Led. Det følges af Nedre Kimmeridgien morke sandede kystfjerne muddersten tilhørende Bernbjerg Formationen.

Den overlejrende syntektoniske Wollaston Forland Gruppe er reprasenteret af kondenserede grå og røde muddersten, der tilhører Albrechts Bugt og Rødryggen Leddene, der begge er af Valanginien alder. Dette er den første dokumentation af forekomsten af Valanginien på Hochstetter Forland. En lagserie af finkornede sandsten og intraformationelle konglomerater på den nordøstligste kyst er med reservation korreleret med de grovere dele af Albrechts Bugt Leddet p̊̊ Niesen i det nordlige Wollaston Forland. Aptien sedimenter er ligeledes påvist for første gang. De er blottede på østkysten nord for Kap Oswald Heer. Hochstetter Forland blokken er endelig placeret tektonisk og palaeogeografisk i det østgrønlandske mesozoiske bassin og er interpreteret som beliggende $i$ en proximal situation $i$ en jurassisk 'failed arm' af en 'triple junction'. 


\section{References}

Bowen, J. M. 1975: The Brent Oil-Field. In Woodland, A. W. (Ed.): Petroleum and the continental shelf of North-West Europe. Applied Science Publishers: 353-361.

Burke, K. \& Dewey, J. F. 1973: Plume-generated triple junctions: key indicators in applying plate tectonics to old rocks. J. Geol. 81: 406-433.

Clemmensen, L. B. \& Surlyk, F. 1976: Upper Jurassic coalbearing shoreline deposits, Hochstetter Forland, East Greenland. Sediment. Geol. 15: 193-211.

Dewey, J. F. \& Burke, K. 1974: Hot spots and continental break-up: Implications for collisional orogeny. Geology 2: $57-60$.

Frebold, H. 1932: Geologie der Jurakohlen des nördlichen Ostgrönland. Meddr Grønland 84 (5): 65 pp.

Frebold, H. 1933: Untersuchungen über die Verbreitung, Lagerungsverhältnisse und Fauna des oberen Jura von Ostgrönland. Meddr Grenland 94 (1): 81 pp.

Kent, P. E. 1975: Review of North Sea basin development. $J$. geol. Soc. Lond. 131: 435-468.

Koch, L. 1929: The geology of East Greenland. Meddr Grønland 73 (2), 1: $204 \mathrm{pp}$.

Koch, L. \& Haller, J. 1971: Geological map of East Greenland $72^{\circ}-76^{\circ}$ N. Lat. (1:250.000). Meddr Gronland 183: $26 \mathrm{pp}$.

Maync, W. 1947: Stratigraphie der Jurabildungen Ostgrönlands zwischen Hochstetterbugten $\left(75^{\circ} \mathrm{N}\right.$.) und dem Kejser Franz Joseph Fjord ( $73^{\circ}$ N.). Meddr Gronland 132 (2): 223 pp.

Maync, W. 1949: The Cretaceous Beds between Kuhn Island and Cape Franklin (Gauss Peninsula) Northern East Greenland. Meddr Gronland 133 (3): 291 pp.

Ravn, J. P. J. 1911: On Jurassic and Cretaceous fossils from North-East Greenland. Meddr Gronland 45 (10): 437-500.

Sommer, M. 1957: Geologische Untersuchungen in den praekambrischen Sedimenten zwischen Grandjeans Fjord und Bessels Fjord $\left(75^{\circ}-76^{\circ}\right.$ N.Br.) in NE-Grönland. Meddr Grønland 160 (2): 56 pp.

Surlyk, F. 1973: The Jurassic-Cretaceous boundary in Jameson Land, East Greenland. In Casey, R. \& Rawson, P. F. (Eds.): The Boreal Lower Cretaceous. Spec. Iss. Geol. J. 5: $81-100$.

Surlyk, F. 1975a: Fault controlled marine fan-delta sedimentation at the Jurassic-Cretaceous boundary, East Greenland. IXth International Congress of Sedimentology, Theme 4 (2): 305-312.

Surlyk, F. 1975b: Block faulting and associated marine sedimentation at the Jurassic-Cretaceous boundary, East Greenland. NPF-Jurassic Northern North Sea Symposium, 7: 1-31.

Surlyk, F. 1977a: Stratigraphy, tectonics and palaeogeography of the Jurassic sediments of the areas north of Kong Oscars Fjord, East Greenland. Bull. Grønlands geol. Unders. 123: $56 \mathrm{pp}$.

Surlyk, F. 1977b: Mesozoic faulting in East Greenland. In Frost, R. T. C. \& Dikkers, A. J. (Eds.): Fault tectonics in N. W. Europe. Geologie Mijnb. 56: 311-327.

Surlyk, F. 1978: Submarine fan sedimentation along fault scarps on tilted fault blocks (Jurassic-Cretaceous boundary, East Greenland). Bull. Gronlands geol. Unders. 128: $108 \mathrm{pp}$.

Surlyk, F. \& Clemmensen, L. B. 1975: A Valanginian turbidite sequence and its palaeogeographical setting (Kuhn Ø, East Greenland). Bull. geol. Soc. Denmark 24: 61-73.

Surlyk, F. \& Clemmsensen, L. B. in press: Jurassic depositional environments in the Wollaston Forland area, East Greenland.
Sykes, R. M. \& Surlyk, F. 1976: A revised ammonite zonation of the Boreal Oxfordian and its application in northeast Greenland, Lethaia 9: 421-436.

Toula, F. 1874: Beschreibung mesozoischer Versteinerungen von der Kuhn-Insel. Zw. Deutsch. Nordpolarfahrt 2: $475-480$.

Vischer, A. 1943: Die postdevonische Tektonik von Ostgrönland zwischen $74^{\circ}$ und $75^{\circ} \mathrm{N}$. Br., Kuhn $\emptyset$, Wollaston Forland, Clavering $\emptyset$ und angrenzende Gebiete. Meddr Gronland 133 (1): 195 pp. 